\title{
CHRISTIANS AT NINEVEH IN LATE ANTIQUITY
}

\author{
By ST J. SIMPSON*
}

The mound of Kuyunjik contains the longest known archaeological sequence of occupation in Mesopotamia, spanning all periods from the sixth millennium BC until at least the thirteenth century AD. The prehistoric periods have been comprehensively studied by Gut $(1995,2002)$ and the general sequence of excavation, occupation and principal architectural finds reviewed by Reade (2000), yet despite a few exceptions (Curtis 1976, 1995; Reade 1998, 1999, 2001; Simpson 1996), the pottery and other finds from the Seleucid period onwards have thus far attracted surprisingly little study. For these periods though, the material culture is characterised by a strong mixture of Classical and Oriental traditions; thus, first-century AD graves contained gold face-coverings and the remains of diadems, both hinting at the eastern extension of practices more commonly found in the eastern Roman provinces, but Western lamps, glassware, ceramics and even a Roman military badge also occur at the site. Some of these betray direct political and military control, whereas others reflect a mixture of imports and local imitations; an appreciation of this rich cultural mix is important for the clearer understanding of Nineveh in Late Antiquity.

Nineveh almost certainly held a Roman garrison at the extreme eastern limit of its empire but following the humiliation of the apostate Julian's Mesopotamian campaign of 363, it must have been ceded as part of the handover of five trans-Tigridian Roman provinces containing Nisibis, Singara, Castra Maurorum and fifteen unnamed forts to Shapur II (309-379). Thereafter the material culture from Nineveh finally acquires an Iranian character and, until its capture in 637/38 or $641 / 42$ by an Arab army generally believed to have been commanded by 'Utba bin Farqad, it flourished as a Sasanian town, bridgehead and fortress on the east bank of the Tigris (cf. Robinson 2000, 36-7). The datable finds of this period include four hoards of silver and bronze coins (Simpson 1996, 95-6); several personal seals, bullae and elaborate cutlery of Sasanian type (Simpson 1996, 97-8; 2003, 362-3, Fig. 3); a range of plain, mould-blown and cut glass (Simpson 2005); and four helmets, the latter hinting at the military component of the settlement referred to in the Arab sources (Simpson forthcoming, $b$ ).

Archaeological data rarely confirm conclusively the ethnic, far less the religious, affiliation of the occupants of a site, yet in this case we can be fairly certain that in addition to the historically attested Jewish community, many of the inhabitants were Christians. These included members of both the Monophysite and Nestorian sects, with the conversion of many of the former to Nestorianism in the late sixth century by one Rabban Qusra, a native of the town (Scher 1908/19, Vol. II/2, 173-4, 199-200; Morony 1984, 308). A pre-Lenten "Fast of Nineveh" was introduced by Sabrisho, metropolitan of Karkha, into the Church calendar in the late sixth century (Fiey 1965/68, Vol. III, 20-2); Church histories refer to a Nestorian bishopric here in the years 554, 576 and 585 subordinate to the metropolitanate of Adiabene at Erbil until the ninth century, when the bishopric was merged with that of Mosul (Sachau 1919, 53; Morony 1982, 14). Famous bishops included Mar Ammeh (catholicos from 644-647), who is said to have offered food to the Arab army at the time of the Conquest (Scher 1908/19, Vol. II/2, 630), and Isaac of Nineveh, who was bishop here under the catholicos George I (658-680) for fewer than six months before resigning to become a leading mystic and writer. Their diocese corresponded to the so-called plain of Nineveh or Ba Nuhadra (Bet Nuhadré) extending from the Tigris opposite Balad to the Great Zab and Jabal Judi.

The increasing importance and influence of Christians by the sixth century are illustrated by the guarantee of freedom of worship and burial in the Sasanian/Byzantine peace treaty of 561; the liturgy included the compulsory naming of "our lord Chosroes, king of kings"; Khusrau I (531-579) himself reconstructed the monastery of S. Sergius at Aynqnayya [Qasr Serij] after it was burnt down by Nestorian protesters; and Khusrau II (591-628) employed several high-

* The British Museum. 
ranking Christians in his Court and army, selected a Christian wife [Shirin] and dedicated gifts to S. Sergius following her conception of a son (Fowden 1999, 128). Thereafter, despite the ambiguities of some of the sources, there continued to be a boom in the building of churches and monasteries across this diocese, judging by the number of attestations in the seventh century when much of the region went Monophysite (cf. Fiey 1965/68, Vol. II).

The province of Adiabene was one of the earliest centres of Eastern Christianity, yet previous studies have almost entirely focused either on the evidence of the Syriac sources (e.g. Scher 1908/19), the standing churches and monasteries (Fiey 1965/68), or the exceptional excavated remains of early churches at Musaifnah and Qasr Serij on the opposite bank of the Tigris (Simpson 1994). This paper illustrates how excavations at Nineveh not only contribute to the growing archaeological evidence for Christianity in the Sasanian empire, reviewed most recently by Hauser (forthcoming), but also the development and spread of a distinctive form of stucco plaque fixed within churches and hitherto regarded as a feature of seventh-to-eighth-century buildings in the Iraqi Western Desert and Gulf region (Fig. 1).

Since Layard's excavations on Kuyunjik began in 1846, almost every subsequent excavator has recovered sherds belonging to what Reginald Campbell Thompson called "the early Christian fabric" (Thompson and Hamilton 1932, 77). The date and distribution of this north Mesopotamian Late Sasanian pottery "type fossil" have been discussed elsewhere but it broadly dates between the late fifth and early seventh centuries (Simpson 1996). The iconography of the stamped designs is more complex than first believed and incorporates design elements from Sasanian art, notably pearl roundel borders and the flowing ribbons attached to the necks of rams and stags (Fig. 2), combined with elements familiar from Mithraic imagery, such as scorpions and snakes. However, one of the most popular motifs is an equal-armed cross, either with straight arms or with splayed ends (a cross patée), and sometimes with smaller crosses in the fields around the main motif (Fig. 3). The frequency of this pottery and the ubiquity of the cross motif, with its unmistakable



Fig. 1. Map of places (drawing by A. Searight). 




Fig. 2. Late Sasanian stamped pottery jar sherd from Kuyunjik (ANE N.1806) (photograph courtesy of The Trustees of the British Museum).

Fig. 3. Detail of Late Sasanian stamped pottery jar sherd from Kuyunjik impressed with the same die as the previous illustrated sherd and showing the cross placed in front of a stag within a toothed border (ANE 1932-12-12,833 =137230) (photograph courtesy of The Trustees of the British Museum).

Christian symbolism, are strong indications of the level of popular tolerance and integration of Christians in Late Sasanian society, as the pots in question are unlikely to have simply been made by or for one religious group (Simpson, forthcoming, $a$ ).

Several other excavated finds strengthen the Christian connection. One is a small lamp of Early Byzantine type (Fig. 4). This measures $11.5 \mathrm{~cm}$ long, $5 \mathrm{~cm}$ across, $8 \mathrm{~cm}$ high, weighs $331.1 \mathrm{gr}$ and has a capacity of $30 \mathrm{ml}$, with a circular handle surmounted by an equal-armed cross with blobs on the terminals of the arms, and a hinged concave lid with the top in the form of a scallop-shell. Its composition was analysed in the Department of Scientific Research and shown to be brass containing $70 \%$ copper, $8.9 \%$ lead, $0.46 \%$ tin and $21.1 \%$ zinc, a composition which appears to have been favoured over bronze for making lamps at this period. The lamp and lid were found in 1904/05 by Reginald Campbell Thompson, in what was described as a late building above the site of the Temple of Nabu (Bailey 1996, 53, 72, Pls. 63, 82, Q3743 + Q3809; Simpson 1996, 97, Pl. Ic). This is one of four sixth-to-seventh-century metal Byzantine-style lamps found at the site (cf. Bailey 1996, 68, 70, 73, Pls. 79, 81, 83, Q3792, 3798, 3811), but the only example with such obvious Christian iconography. A similar lamp was found during the 1898/99 season of excavations in the uppermost "level" in Trench 15 on the Acropole at Susa, where it was rapidly cited as evidence for "une colonie chrétienne" there during the Sasanian period (de Morgan, Jéquier and Lampre 1900, 121-2, Fig. 259); another example was reportedly acquired in Nihavend in western Iran (Exhibition of Iranian Art, June-August 1956, Rome, No. 279, Pl. XLVI). These lamps belong to a type better known from the Byzantine empire, including Egypt (Bailey 1996, Q3788, 3822, 3823 ) and more recent excavations of a fifth-century or later church at ancient Ostrakine in north Sinai (Oren 1993, 311). They were originally mounted on a pointed rectangular spike on top of a pricket stand with three feet, of which a number of examples have been found in Egypt, Syria and Sardis, and dated between the fifth and early seventh centuries (Waldbaum et al. 1983, 104, Pl. 40, No. 615). 

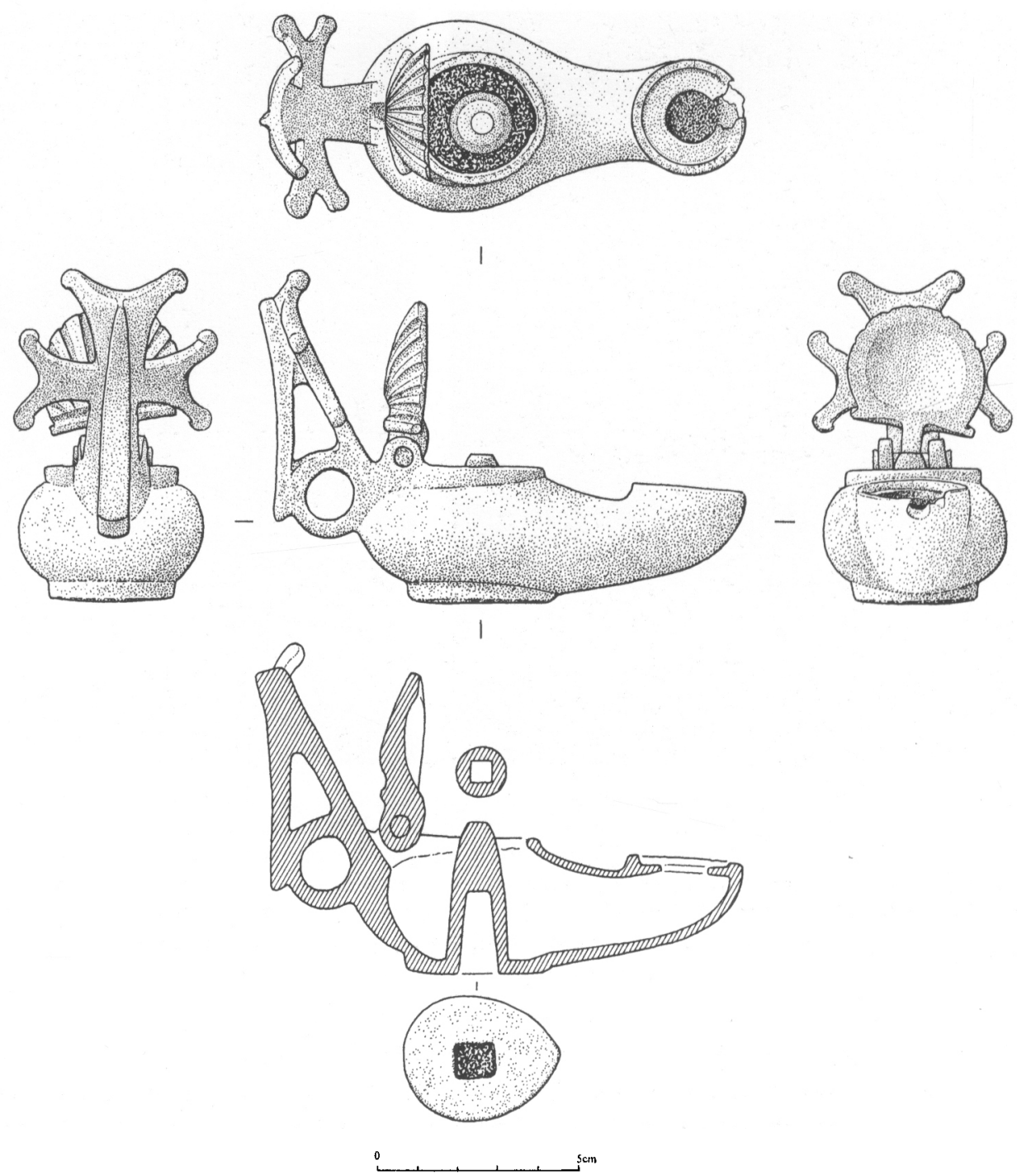

Fig. 4. Brass lamp of Early Byzantine type (ANE 1905-4-9,436+443=98930+98937) (drawing by A. Searight).

The second find is a cast copper alloy censer or thymiaterium, with a hexagonal bowl with an everted ledge rim, flat bottom and three cast feet (Fig. 5). It measures $5.7 \mathrm{~cm}$ high, $8.1 \mathrm{~cm}$ across, weighs $239.7 \mathrm{gr}$ and has a capacity of $100 \mathrm{ml}$. According to the mosaic of Justinian and his retinue from San Vitale at Ravenna, executed between 538 and 548, this type was originally swung in the priest's right hand by chains passed through the three loops on the upper rim. This object was recovered from excavations by Thompson in Trench SW IV, 4 above Sennacherib's Palace (Thompson and Mallowan 1933, PI. LXXVIII: 1). Only one other example of this type appears to have been found in a Sasanian context, again from Susa. It consists of a three-legged cylindrical censer, with its chain intact. Both belong to a western type dating between the fifth and early seventh centuries and found throughout the Levant, at Sardis (Waldbaum et al. 1983, 98-9, Pl. 37, Nos. 577-80), and as far west as Spain (Almagro Gorbea 1964/65, 181-201).

In 1929/30 and 1930/31, Thompson excavated an extensive area around the Temples of Nabu and Ishtar in the centre of Kuyunjik. Judging by the schematic published sections, some 3.5 metres of later stratigraphy were present here and although the excavators struggled to recognise architectural remains other than "cement" floors, reused-brick paving and short sections of walling, they did discover a substantial number of Sasanian finds, including one of four helmets to be recovered 

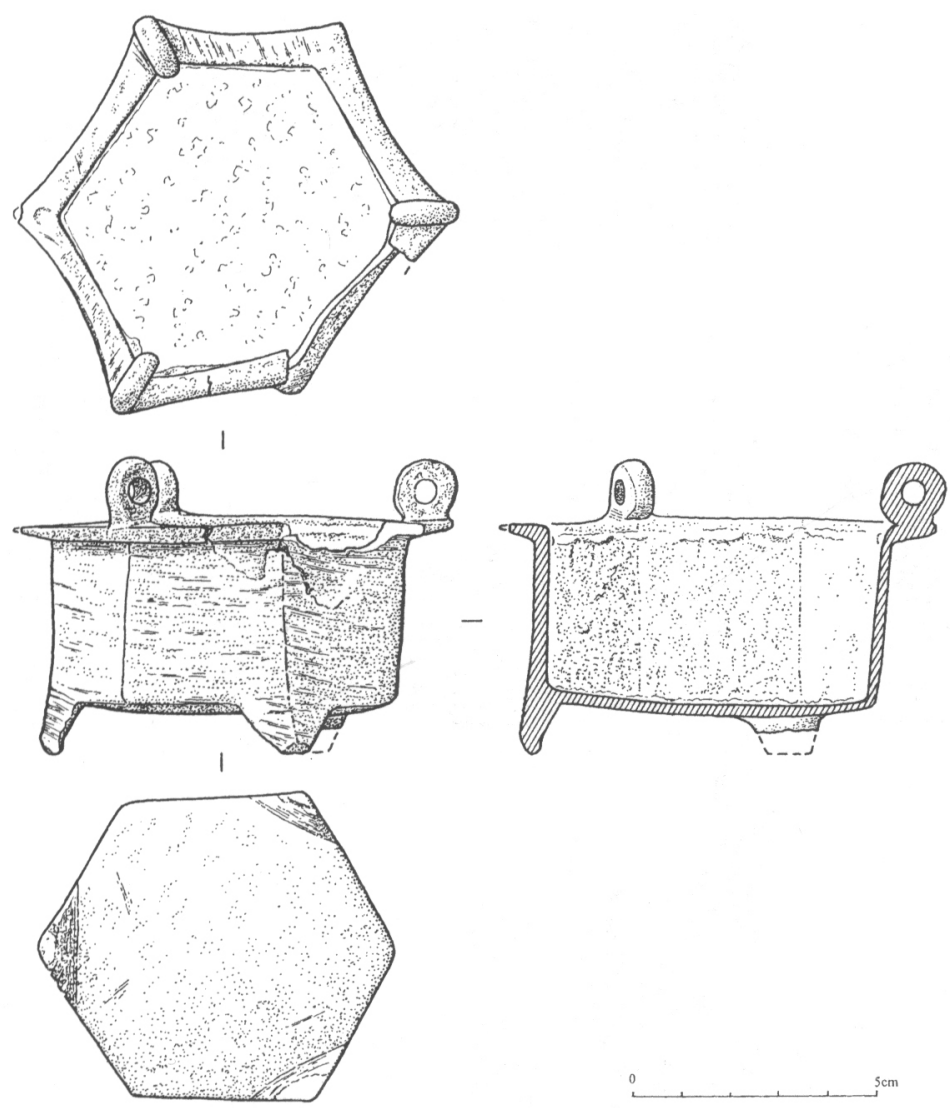

Fig. 5. Copper alloy thymiaterium of Early Byzantine type (ANE 1932-12-12,7=124277) (drawing by A. Searight).

at the site, coins, stamped pottery, glassware, and a small copper alloy buckle. This was in the form of an equal-armed cross with blobs on the terminals and a pair of flowing ribbons issuing from the (broken) base; it was recovered from Trench IV,4 on the east side of the Nabu Temple platform (Thompson and Hutchinson 1929, Pl. LXIX: 289).

From nineteenth-century excavations on Kuyunjik come three sherds belonging to one or more conical glass lamps decorated with blue prunts (Fig. 6). This type of decoration is rather alien in the Sasanian world where reflectiveness through cut faceting was preferred over the Roman tendency to add artificial colours. The sherds belong to a fourth-to-fifth-century eastern Roman type which, judging by mosaic depictions and excavated finds, was typically used in churches and synagogues in Syria-Palestine and Anatolia; some of these are also decorated with cruciform motifs and they occasionally contain oily residues (Lightfoot 1989, 39-40, 43-5; Weinberg (ed.) 1988, 87-94, col. Pl. 4c, Pls. 4-18). Interestingly, this type is only otherwise known within the Sasanian empire from excavations at the city of Veh Ardashir, a city where two churches and a synagogue are attested in the written sources (Negro Ponzi 1984, 34).

In 1873/74, George Smith recovered a carved plaque fragment measuring $10.5 \mathrm{~cm}$ high, $6.5 \mathrm{~cm}$ across and $2.7 \mathrm{~cm}$ thick, depicting a low-relief cross with lightly flaring decorated arms (Fig. 7). It was presumably mounted on or set into a wall of a building, and thus resembles the function of the last find. This is a fragmentary painted stucco plaque, now measuring $7 \mathrm{~cm}$ high and $7.3 \mathrm{~cm}$ across, found in 1931/32 near the centre of Kuyunjik at a depth of -1 foot below datum in square MM, i.e. near the top of Mallowan's deep sounding on the west side of the Temple of Ishtar. This plaque originally measured some $10 \mathrm{~cm}$ across, was $1.6 \mathrm{~cm}$ thick, had a flat back, lightly bevelled sides and a smooth decorated front (Figs. 8-9). This was cut and incised to represent a cross with splayed arms decorated with compass-incised circles at the ends, and shown 

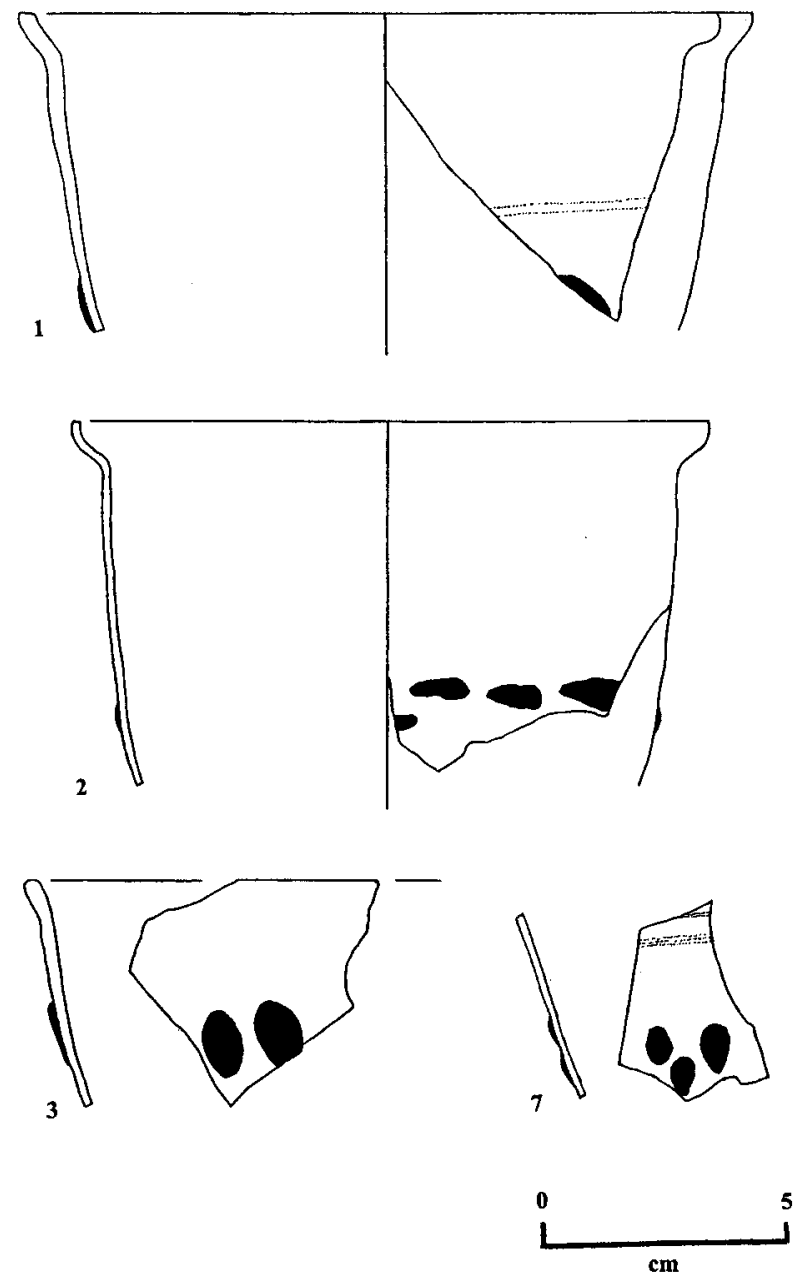
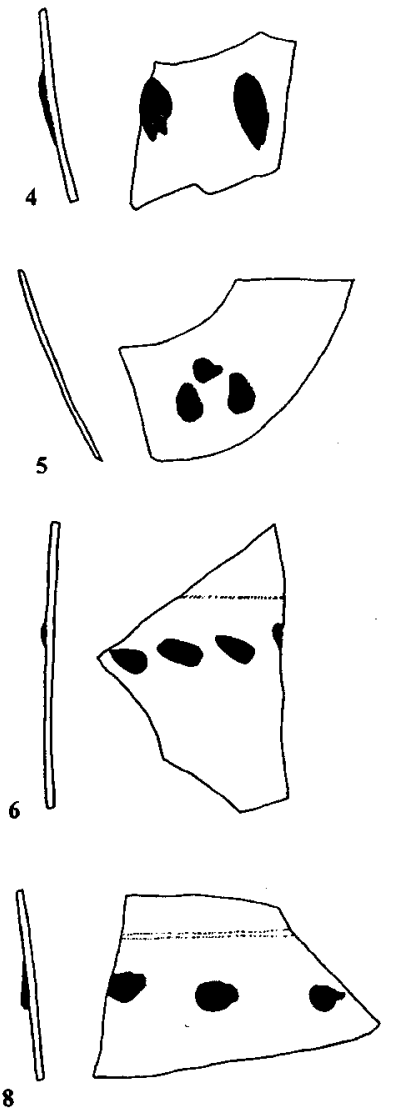

8

Fig. 6. Imported Late Roman glass lamps from Kuyunjik. All are transparent with darkblue prunts: 1. Ashmolean Museum, B21, ext. rim diameter $15 \mathrm{~cm}$, cracked-off rim, wheelabraded line on the exterior; 2. Birmingham City Museum \& Art Gallery, 702'61, ext. rim diameter $13 \mathrm{~cm}$, cracked-off rim, pale olive-green tinge; 3 . British Museum, ANE N.1464, rim diameter uncertain; 4. British Museum, ANE N.1405; 5. Ashmolean Museum, B21 (xxv,4), angle tentative; 6. British Museum, ANE N.1403, angle uncertain; 7. Ashmolean Museum, B21, wheel abrasion on the exterior, angle approximate; 8. Ashmolean Museum, B21 (xxvii,A8), wheel abrasion on the exterior, angle uncertain.

beneath a niche or arch; further circles were incised above and the borders of the composition defined by pairs of broad vertical incised lines. The incision was highlighted with red ochre.

This Nineveh plaque finds close parallels on incised plaques found in seventh-to-eighth-century churches at Ain Sha'ia and al-Hira in the Iraqi Western Desert. These represent a form of icon, originally believed to have been wall-mounted, and not just at home within Christian monastic communities on the desert fringes of southern Mesopotamia but also evidently employed within this major town in northern Mesopotamia. These icons fall into two contemporary groups. The first consisted of rectangular moulded plaques depicting a Latin cross with splayed arms, the ends of which terminated in small blobs; some or all of these crosses were raised on a stepped base, representative of Calvary, and occasionally embellished with ribbons flowing upwards from the bottom to symbolise a cross of glory, as well as possibly harking back to a leitmotif of Sasanian royal imagery where it symbolised xwarneh or divine grace. These crosses were also occasionally shown within a nimbus-like arch with three rosettes in the field above (representing the Trinity), and enclosed within a plain or decorated outer border. The largest single group of these plaques comes from a seventh-to-eighth-century church at Ain Sha'ia (Okada 1990) but other examples 


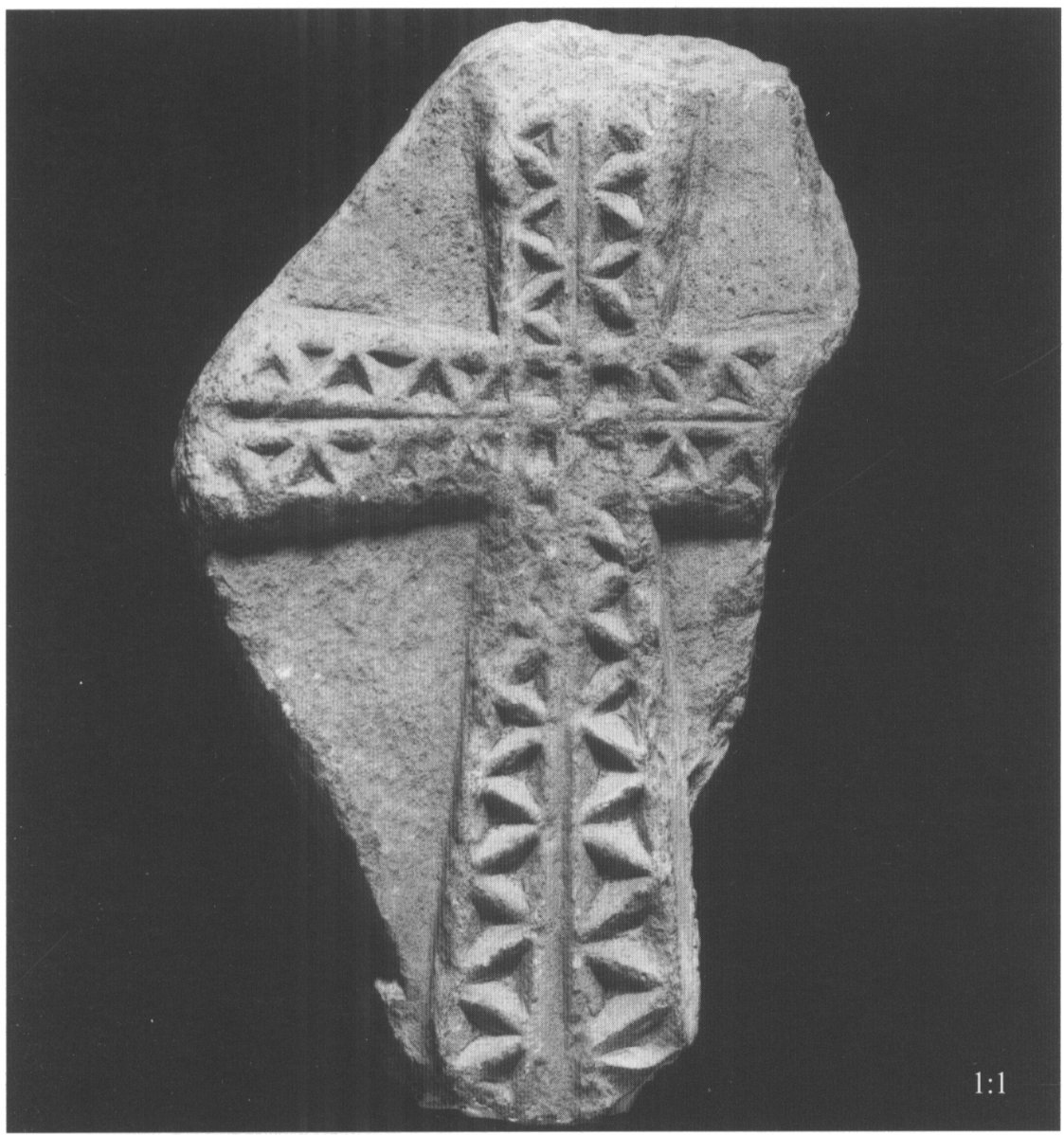

Fig. 7. Cruciform plaque from Smith's excavations on Kuyunjik (ANE S.2237=92268) (photograph courtesy of The Trustees of the British Museum).

were found at al-Hira (Talbot Rice 1932a, 282-3, Figs. 3c-h, 4a, c; Talbot Rice 1932b), Akkaz (Gachet 1998, 73, 76, Fig. 14) and Failaka (Bernard and Salles 1991, 9-10, Fig. 2). The second group consisted of finely incised plaques decorated with crosses and dotted circles with red and occasionally black pigment infilling the cut portions. Examples of this type have been recovered both from Ain Sha'ia (Okada 1990, Fig. 1: 8-9) and from two churches excavated in Mounds V and XI at al-Hira (Talbot Rice 1932a, 282-3, Fig. 3a-b; Talbot Rice 1934, 70-3, Fig. 24B). A similar style of incised decoration characterises Umayyad pottery from southern Iraq, suggesting that the decoration on this second group may be part of a new decorative concept. The use of black and red pigment was likewise noted on plaques found at Ain Sha'ia (Okada 1990, 107).

The archaeological evidence thus implies a strong Christian presence on Kuyunjik at least between the fifth and eighth centuries. Some of the finds belonged to private householders, whereas others must certainly have been set up within a church or monastery. Fiey (1965/68, Vol. II, 325, 497-9), followed by Oppenheimer (1983, 312-13), speculated that Nebi Yunus may have been the centre of the Christian population of Nineveh but the much greater depth of post-Assyrian stratigraphy at Kuyunjik compared with that evident in the 1987 Iraqi excavations at Nebi Yunus, coupled with the finds discussed here, points instead to Kuyunjik. It is difficult to visualise the appearance of the settlement at this period although the textual sources imply that it was walled. Hitherto excavations have either tended to disregard the later stratigraphy, or to rely on tunnelling, sounding or deep trenching with regular backfilling, rather than open-area excavations. In addition, none of the excavators appears to have consistently recognised vernacular mud-brick architecture surviving only a few courses high. The few published plans of "late period" architecture thus tend to be multi-period and highly confused. However, they do at least suggest the existence in the 

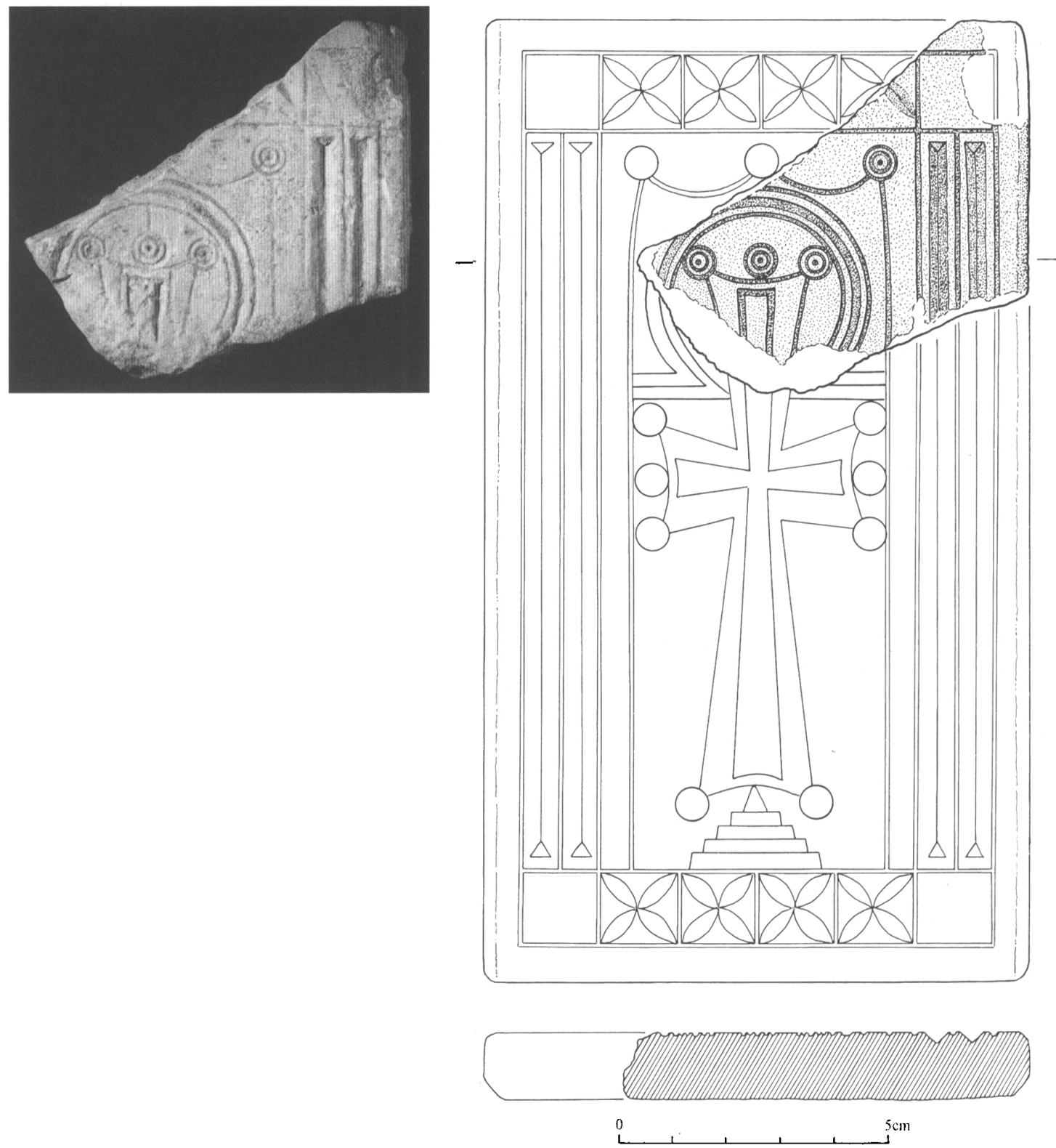

Fig. 8. Cut and painted stucco plaque (ANE 1932-12-12,1129=138596) from square MM-1 at Kuyunjik (photograph courtesy of The Trustees of the British Museum).

Fig. 9. Suggested reconstruction of the Nineveh plaque (drawing by A. Searight).

centre of the mound of a regular cobbled streetplan with mud-brick buildings built on stone footings (Thompson and Hutchinson 1931, Pl. XXXIX; Thompson and Hamilton 1932, Pls. XCI$\mathrm{XCII}$ ). The prospect is bleak for the renewed excavation of such levels in the foreseeable future, yet this underlines the importance of old collections in the continuing interpretation of the significance of Nineveh in antiquity.

\section{Bibliography}

Almagro Gorbea, M., 1964/65. Un nuevo incensario de época visigoda halado en España, Ampurias 26/27, $181-201$.

Bailey, D. M., 1996. A Catalogue of the Lamps in the British Museum. IV. Lamps of Metal and Stone, and Lampstands, London.

Bernard, P. and Salles, J.-F., 1991. Discovery of a Christian church at al-Qusur, Failaka ( Kuwait), Proceedings of the Seminar for Arabian Studies 21, 7-21. 
Curtis, J. E., 1976. Parthian gold from Nineveh, The British Museum Yearbook 1. The Classical Tradition, 47-66, London.

Curtis, J. E., 1995. Gold face-masks in the Ancient Near East, The Archaeology of Death in the Ancient Near East (Campbell, S. and Green, A., eds), 226-31, Oxford.

De Morgan, J., Jéquier, G. and Lampre, G., 1900. Fouilles à Suse en 1897-1898 et 1898-1899, Mémoires de la Délégation archéologiques, tome I: Recherches archéologiques, première série, Paris: Ernest Leroux.

Fiey, J.-M., 1965/68. Assyrie chrétienne, Beirut; 3 vols.

Fowden, E. K., 1999. The Barbarian Plain. Saint Sergius between Rome and Iran, Berkeley/Los Angeles/ London.

Gachet, J., 1998. 'Akkaz (Kuwait), a site of the Partho-Sasanian period. A preliminary report on three campaigns of excavation (1993-1996), Proceedings of the Seminar for Arabian Studies 28, 69-79.

Gut, R. V., 1995. Das prähistorische Ninive. Zur relativen Chronologie der frühen Perioden Nordmesopotamiens, Baghdader Forschungen 19, Mainz.

Gut, R. V., 2002. The significance of the Uruk sequence at Nineveh, Artefacts of Complexity. Tracking the Uruk in the Near East (Postgate, J. N., ed.), 17-48, Warminster.

Hauser, S. R., forthcoming. Christliche Archäologie im Sasanidenreich. Grundlagen der Interpretation und Bestandsaufnahme der Evidenz. Inkulturation des Christentums im Sasanidenreich; Proceedings of a conference at Leucorea, Wittenberg, May 1999 (Tübach, J. and Araba, S., eds), Wiesbaden.

Lightfoot, C. S., 1989. A Catalogue of Glass Vessels in Afyon Museum/Afyon Müzesindeki Cam Eserler Katalogu, Oxford.

Morony, M. G., 1982. Continuity and change in the administrative geography of Late Sasanian and Early Islamic al-'Iraq, Iran 20, 1-49.

Morony, M. G., 1984. Iraq after the Muslim Conquest, Princeton.

Negro Ponzi, M. M., 1984. Glassware from Choche (Central Mesopotamia), Arabie Orientale, Mésopotamie et Iran méridional de l'age du fer au début de la période islamique (Boucharlat, R. and Salles, J.-F., eds), 33-40, Paris.

Okada, Y., 1990. Reconsideration of plaque-type crosses from Ain Sha'ia near Najaf, Al-Rafidan 11, $103-12$.

Okada, Y., 1991. Early Christian architecture in the Iraqi south-western desert, Al-Rafidan 12, $71-83$.

Okada, Y., 1992. Ain Sha'ia and the early Gulf churches: An architectural analogy, Al-Rafidan 13, 87-93.

Oppenheimer, A., 1983. Babylonian Judaica in the Talmudic Period, Wiesbaden.

Oren, E. D., 1993. A Christian settlement at Ostrakine in north Sinai, Ancient Churches Revealed (Tsafrir, Y., ed.), 305-14, Jerusalem.

Reade, J. E., 1998. Greco-Parthian Nineveh, Iraq 60, 65-83.

Reade, J. E., 1999. An Eagle from the East, Britannia 30, 286-8, Pl. XXIIIa.

Reade, J. E., 2000. s.v. Ninive (Nineveh), Archäologie, Reallexikon der Assyriologie und Vorderasiatischen Archäologie 9/5-6, 388-433.

Reade, J. E., 2001. More about Adiabene, Iraq 63, 187-99.

Robinson, C. F., 2000. Empire and Elites after the Muslim Conquest. The Transformation of Northern Mesopotamia, Cambridge.

Sachau, E., 1919. Zur Ausbreitung des Christentums in Asien, Berlin.

Scher, A., 1908/19. Histoire nestorienne inédite, Chronique de Séert, Paris.

Simpson, St J., 1994. A note on Qasr Serij, Iraq 56, 149-51.

Simpson, St J., 1996. From Tekrit to the Jaghjagh: Sasanian sites, settlement patterns and material culture in northern Mesopotamia, Continuity and Change in Northern Mesopotamia from the Hellenistic to the Early Islamic Period (Bartl, K. and Hauser, S. R., eds), 87-126, Pls. 1-2, Berlin.

Simpson, St J., 2003. From Mesopotamia to Merv: Reconstructing patterns of consumption in Sasanian households, Culture through Objects. Ancient Near Eastern Studies in Honour of P.R.S. Moorey (Potts, T., Roaf, M. and Stein, D., eds), 347-75, Oxford.

Simpson, St J., 2005. Sasanian glass from Nineveh, Annales du l6e Congrès de l'Association internationale pour l'histoire du verre (London, July 2003), 146-51.

Simpson, St J., forthcoming, a. First class stamps: Late Sasanian pots, potters and people in northern Mesopotamia, Baghdader Mitteilungen.

Simpson, St J., forthcoming, $b$. Sasanian helmets from Nineveh, Proceedings of the International Conference of Arms and Armament in Parthian and Sasanian Times (Mode, M. and Tübach, J., eds), Halle.

Talbot Rice, D., 1932a. The Oxford Excavations at Hira, 1931, Antiquity 6, 276-91, Pls. 1-VIII.

Talbot Rice, D., 1932b. Hira, Journal of the Royal Central Central Asia Society (April), 254-68.

Talbot Rice, D., 1934. The Oxford Excavations at Hira, Ars Islamica 1/1, 51-73.

Thompson, R. C. and Hamilton, R. W., 1932. The British Museum excavations on the Temple of Ishtar at Nineveh, 1930-31, [Liverpool] Annals of Archaeology and Anthropology 19, 55-116, Pls. XLVIXCII.

Thompson, R. C. and Hutchinson, R. W., 1929. The Excavations on the Temple of Nabu at Nineveh, Archaeologia 79, 103-48, Pls. XLI-LXV. 
Thompson, R. C. and Hutchinson, R. W., 1931. The Site of the Palace of Ashurnasirpal at Nineveh, excavated in 1929-30 on behalf of the British Museum, Archaeologia 79, 103-48, Pls. XLI-LXV.

Thompson, R. C. and Mallowan, M. E. L., 1933. The British Museum Excavations at Nineveh, 1931-32, [Liverpool] Annals of Archaeology and Anthropology 20, 71-186, Pls. XXXV-CVI.

Waldbaum, J. C. et al., 1983. Metalwork from Sardis: The Finds through 1974, Cambridge [Mass.].

Weinberg, G. D., ed., 1988. Excavations at Jalame. Site of a Glass Factory in Late Roman Palestine, Columbia. 